\title{
Transition from Conventional to Organic Farming Systems: I. Challenges, Recommendations, and Guidelines for Pest Management
}

Gladis M. Zinati

\begin{abstract}
Additional InDEX wORDs. alternative agriculture, biological approach, cover crops, crop rotation, cultural practices, disease management, insect management, nematode control, organic amendments, weed management
\end{abstract}

Summary. Conventional agricultural systems increase per-area food production, but deplete natural resources and degrade both crop and environmental quality. Many of these concerns are addressed by sustainable agricultural systems, integrated pest management, biocontrol, and other alternative systems. Environmental and social concerns have escalated the need for alternative agricultural systems in the last decade. One alternative, the organic farming system, substitutes cultural and biological inputs for synthetically made fertilizers and chemicals for crop nutrition and pest management. Practices used for crop and pest management are similar during transition from conventional to organic farming systems, but produce is not certified to be organic during the transition period. During the transition from conventional to organic farming, growers may face pest control difficulties and lower yields when conventional practices are abandoned. The objectives of this paper are to 1) give an overview of the reasons for converting to organic farming and the challenges that growers face during the transition period, 2) outline some potential strategies for crop, soil, and pest management, and 3) list guidelines and recommendations for pest management during the transition to organic farming. Implementation of crop and pest management practices depends on geographical location, climate, available onsite resources, and history of the land. During transition, growers rely on cultural mechanisms and on organic and mineral sources to improve soil fertility, to build a population of natural enemies to suppress pest populations. Pest management practices during the transition period that reduce pest populations to economically manageable levels include crop rotation, cultivation, cover crops, mulches, crop diversification, resistant varieties, and insect traps. These practices also enrich the soil biota and increase crop yields before produce is certified organically grown.
Oonventional farming systems have increased per-area yield while reducing labor requirements. Factors responsible for yield increases include use of new plant varieties that use fertil- izer more efficiently, cultural practices (e.g., increased crop density), higher fertilizer rates, efficacious pesticides, and increased mechanization in crop harvesting (Oelhaf, 1978). However, many of these practices deplete natural resources (nonrenewable energy) and degrade crop quality and the environment (Hamilton and Helsel, 1995; Rasse et al., 2000).


Conventional practices contribute to 1) depletion of nonrenewable energy resources to produce pesticides, fertilizers, and to power mechanized equipment, 2) air, water, and health hazards, and 3 ) reduction of soil quality. For example, in some areas, growers used excessive rates of synthetic fertilizers to attained high yields, but contaminated groundwater (Canter, 1996; Sartain, 1990; Snyder et al., 1984). Increased frequency of tillage without addition of organic amendments (e.g., manure, compost, crop mulches, etc.) led to reduced soil organic carbon and increased soil erosion where soil surfaces were left bare (Ayers, 1936). In some regions of the U.S., such as Florida, growers used soil fumigants (primarily methyl bromide) to ensure pest control under intensive crop production for many decades. However, the use of this fumigant has been linked to ozone depletion and is now being phased out under the Montreal Protocol (U.S. Department of Agriculture, 2001).

Based on these concerns, researchers and producers are looking for alternative agricultural production methods that can reduce damage to the environment. Among these alternatives is organic farming.

Organic farming is defined as a production system that avoids or largely excludes the use of synthetic fertilizers, pesticides, growth regulators, and livestock feed additives. To the maximum extent feasible, organic farming systems rely upon crop rotation, crop residues, animal and green manures, off-farm organic wastes, mechanical cultivation, mineral-bearing rocks, and biological pest control to maintain soil productivity and tilth, supply plant nutrients, and control insects, weeds, and other pests (U.S. Department of Agriculture, 1980).

The purpose of this paper is to 1 ) review the reasons for conversion to organic farming and the challenges that growers face during transition, 2) outline strategies for crop, soil and pest management, and 3) focus on guidelines and recommendations for pest management to minimize yield losses to pests during transition to organic farming.

\section{Reasons behind conversion to organic farming}

Organic farming is viewed as an environmentally friendly and consumeroriented approach to food production.
Some conventional producers perceive a need to change to organic farming for a variety of reasons. Some see organic farming as a profitable system. Others are attracted because they feel it is personally satisfying, or an environmentally sound and a healthier alternative to conventional farming. In general, motivations for organic farming typically are eitherfarm-related or personal (Lampkin and Padel, 1994; Thompson, 2000). Farm-related motivations include husbandry (e.g., previous problems with conventional production) or financial factors (e.g., higher prices for fresh organic produce). Personal motivations include personal health (e.g., less exposure of farm workers to pesticides), availability of foods grown by locally owned, small family farms and religious, philosophical, political and environmental beliefs.

Organic production increased rapidly in the last decade (Dunn, 1995; Thompson, 2000). In 2000, sales by the organic industry were worth $\$ 6$ billion and have grown at a rate of $12 \%$ per year during the last 8 years (U.S. Department of Agriculture, 2000). Currently, organic production represents the largest growth segment in the U.S. Certified organic cropland more than doubled, from 403,400 to 850,173 acres $(161,360$ to 340,069 ha) from 1992 to 1997 , but the percentage increase was less than the organic livestock, eggs and dairy sectors (Greens, 2001).

Conversion from conventional to organic farming system requires a 3 year transition period before produce may be certified organically (U.S. Department of Agriculture, 1990). Soil and pest management practices will be the same during and after transition. However, during the transition period, growers may face difficulties in maintaining crop yields and control pests once conventional methods are abandoned.

\section{Challenges during conversion to organic farming}

During transition to organic production systems, growers experience a period of suppressed yields, followed by a return to yields near or equal to those achieved with conventional production (Clark et al., 1998; Peters, 1991). This transition effect has been attributed to time required for changes in chemical, physical and biological properties of soil necessary to enhance nutrient cycling, plant growth, and development of biological pest control within the system.

During the transition period, growers spend time testing and searching for cultural, chemical and biological practices, following organic system guidelines to reduce pest pressures by building soil beneficial organisms and restoring soil organic carbon. These changes may take longer than 1 year. In some cases, growers may need to adjust existing equipment or purchase additional equipment to cope with the extra stubble for seeding or transplanting (Morse, 1999). Other challenges are coping with yield losses due to abrupt changes in soil and pest management, and reduced profitability.

\section{Strategies for soil management during transition}

SOIL MANAGEMENT DURING THE TRANSITION PERIOD IS AS IMPORTANT AS Pest MANAGement. Successful implementation of appropriate cultural and biological practices depends on growers' time, patience, and expertise. During the transitional period, growers gain experience and as soil organic matter builds, the benefits are reflected in improved soil characteristics.

During the transition period, growers will rely on inorganic and organic materials to improve soil quality and build up beneficial organisms to reduce pest populations. Such materials include gypsum, dolomite, potassium magnesium sulfate, cover crops, feather meal, composts, peatmoss, fish emulsion, and seaweed extract to provide nutrients.

Cover crops and composts increase soil quality by improving biological, chemical and physical properties, including organic carbon content (Hoffmann, 1983; Zinati et al., 2001), cation exchange capacity (Khaleel et al., 1981; Zinati and Emino, 2002), aggregate stability and water infiltration rate (Dabney et al., 2001), reduced levels of soil nematodes and other pathogens (Gallards-Lara and Nogales, 1987), and improved plant tolerance to nematodes (McSorley and Gallaher, 1995).

Plants such as rye (Secale cereale) and vetch (Trifolium spp.) provide nutrients and organic matter to soil (Bowman et al., 1998). Legume (Fabaceae) cover crops supply nitrogen $(\mathrm{N})$ to subsequent crops and when sown with 
grass seed often increase total carbon inputs without sacrificing $\mathrm{N}$-scavenging efficiency (Ofori and Stern, 1987). Other cover crops, especially nonleguminous crops, are better at scavenging residual $\mathrm{N}$ before it can leach (Jackson et al., 1993). Often the plant varieties selected for planting are also pest or disease resistant (Dabney et al., 2001; Muehlbauer, 1996).

Amending soil with organics increases availability of soil nutrients as well as increases microbial population and activity (Gallards-Lara and Nogales, 1987). During a 4-year study, Scow et al. (1994) found that soil organic matter, soil $\mathrm{pH}, \mathrm{N}$, phosphorus (P) and potassium $(\mathrm{K})$ levels were consistently higher in organic than conventional systems. Microbial biomass levels were consistently higher in organic and low input systems while plant parasitic nematode numbers were consistently lower than those in conventional systems.

Some crops, when grown organically, may exhibit nitrogen deficiency during the transition period (Scow et al., 1994). This deficiency was most prominent in organically grown tomato (Lycopersicon esculentum). Nitrogen deficiencies may be reduced by repeated application of organic $\mathrm{N}$, either by green manuring or preplant application of compost. Also, Gaskell (1999) showed that feather meal performed the best among seven tested organic fertilizers on bell pepper (Capsicum annuиm). Materials such as gypsum, lime, or potassium magnesium sulfate can be used to correct deficiencies or imbalances, raise soil $\mathrm{pH}$, leach out excess exchangeable sodium via Ca replacement, and/ or improve soil water infiltration (Gaskell et al., 2000).

\section{Strategies for pest management during transition}

Growers may use many strategies to achieve acceptable economic pest management and high yields. During the transitional period, weed management can be enhanced through cultural and chemical practices, while insect and nematode management will depend on cultural and biological control methods. Disease management will be based on strategies having an ecological basis.

Weed management. During and after transition periods, the weed seed bank may be reduced through cultivation, chipping and hand-weeding, in- terrow cultivation, straw mulch, palletized paper-waste mulch, flame weeding and the use of weed mats (Kristiansen, 2000), crop competition, and cover crop residues (Teasdale, 1993), water management, solarization, and chemical controls such as acetic acid, corn gluten, and citric acid (Fernandez-Cornejo etal., 1998; Gaskell et al., 2000). Other methods useful for all crops and essential for long-term weed management include a program of crop rotations, including green manure crops between cash crops, preplanting cultivation, slashing/mowing to avoid seeding, maintaining good farm hygiene, and avoiding procrastination (Fernandez-Cornejo et al., 1998).

INSECT AND NEMATODE MANAGEMENT. Growers use prevention approaches as primary strategies in controlling insects during the transition period. They rely on a diverse population of soil organisms, beneficial insects, birds, and other organisms to keep insect problems in check to produce cleaner plants exhibiting less insect damage. Monitoring for insects and proper identification of immature life stages of an insect will greatly aid in preventing economic damage to crops. When pest populations get out of balance, growers may implement a variety of strategies including 1) insect predators such as ladybugs (Coccinellidae), lacewings (Neuroptera), syrphid flies (Syrphidae), or parasitic wasps (Hymenoptera) to control aphids (Aphididae) and other pest populations (Corbett and Rosenheim, 1996; Gaskell et al., 2000; Yespen, 1976), 2) mating disruption through pheromones (Wang et al., 1997), and 3) traps and barriers (Yepsen, 1976).

Some microbial insecticides such as BTS (Bacillus thuringiensis subspp.) are readily available and their primary use is to kill larvae of butterflies and moths(Lepidoptera). However, in some cases, due to repeated applications of these pesticides, insects may develop resistance and over time pesticides may become less effective. Insects are less likely to develop resistance to soaps and oils. These chemicals control insects by physical actions such as suffocating or dislodging insects from the crop (Gaskell et al., 2000).

The incorporation of cover crops into crop rotation is recommended. Some grass species tend to be resistant to nematodes of the more common cash crops (Weaver et al., 1998). Resis- tant cultivars and trap crops are useful in controlling the buildup of damaging nematode species (Halford et al., 1999).

Disease management. Growers may be faced with various disease problems due to elimination of synthetic fungicides and fumigants on many crops they might produce during the transition period. Disease management can be incorporated within the general production practices of weed, insect, nematode and soil management. Such practices may include site selection, alternate host exclusion, resistant cultivars and plant stocks, fungicides approved for organic farming, crop rotations, mulches, cover crops and composts. The soil management practices will encourage diversity of soil-inhabiting and leaf-epiphytic microorganisms that might have beneficial and pathogenantagonistic effects.

Growers must be careful when selecting sites for organic farming, especially sites that have histories of soilborne pathogens such as Fusarium, Phytophthora, Pythium, and Rhizoctonia. However, this strategy may be less helpful in California, where these pathogens are widespread and the use of resistant cultivars or plant stocks would be a better practice (Gaskell etal., 2000).

Sometimes, it is necessary to apply protectant or eradicant spray or dust materials for disease control. However, growers are faced with limited choices of effective and proven materials that can be used during and after the transition period. Copper-based fungicides have some activity against a wide range of bacterial pathogens, but are less effective than sulfur, which provides excellent control against many pathogens.

Multitactic pest management. Some cultural management practices used to improve soil quality and may have concurrent suppressive effects on various pests. These may include, but are not limited to crop rotations, solarization, cover crops, and mulches.

Crop rotations are an essential component of successful organic production systems. By sequentially growing different crops in the same fields, crop diversity in both space and time is achieved and pest problems are minimized. Rotations maintain soil fertility, soil structure and soil organic matter (Opperman et al., 1988), and also suppress root-knotnematodes (Meloidogyne spp.) This nematode suppression can be achieved by incorporating some cover crops that are resistant or tolerant of 
root-knot nematodes in crop rotation designs. These may include some legumes (Gallaher and McSorley, 1993) such as cowpea (Vigna unguiculata) and velvetbean (Mucuna deeringiana), or grasses (Poaceae) such as oats (Avena sativa). Numerous crop rotation recommendations exist, but five proven examples are as follows.

1) Planting shallow-rooted crops such as onion (Allium cepa) after deeprooted cover crops such as rye (Secale cereale) (Willumsen and ThorupKristensen, 2001). These help in keeping the soil structure open and assist drainage.

2) Alternating cover crops of high root biomass (erosion prevention plants), such as rye, sorghum-sudangrass hybrids (Sorghum bicolor x S. bicolor var. sudanese) with low root biomass (soil builders) such as crimson clover (Trifolium incarnatum) (Bowman et al., 1998). High root biomass crops provide organisms as earthworms with material food substrates (Decaens et al., 1999).

3) Alternating between crops that are resistant and susceptible to weed infestations is recommended. Crops susceptible to diseases should only occur in the rotation when disease pressure is lowest.

4) Soil solarization has been found to be effective in reducing many soilborne pathogens and other pests (Katan and DeVay, 1991;McGovern and Begeman, 1996).

5) Wheat (Triticumaestivum) and straw mulch may be used to control weeds, and crops such as sorghum (Sorghum bicolor) are rotated to suppress soil diseases and nematodes (Papedick and Cook, 1974; McSorley, 1998). Timing, management of organic inputs and using appropriate equipment are important factors for the success of transitional systems (Temple et al., 1994).

\section{Recommendations for minimizing transitional problems}

A transition process must involve some kind of structural or fundamental change in the farm operation. One input cannot simply be substituted for another (manure for ammonium nitrate). The following practices are helpful in reducing some of the problems a farmer may face during the conversion period (Papendick and Elliot, 1984;
Peters, 1991; Voss and Shrader, 1984).

1) Selection of land with high nutrient status, good soil structure, and low pest pressure.

2) Including pest-resistant leguminous crops in a crop rotation design to supply $\mathrm{N}$ and reduce pest populations.

3) In the first year of transition, planting a crop with less $\mathrm{N}$ requirement may offset some problems associated with low soil $\mathrm{N}$.

4) Routine application of green manure and organic wastes as manure increases soil organic matter, water infiltration, and reduces soil erosion.

5) Although a 3-year transition period is required before certification of organically grown produce, a 3- to 5year transitional period is recommended to allow yields to stabilize before applying for certification.

6) Alternation of cool season crops with warm season crops to interrupt weed cycles.

7) Disking and overseeding in a timely manner are recommended to keep weeds under control.

8) Choosing cultivation techniques that are practical and economical.

Guidelines for pest management during transition to organic farming system

The adoption of any of the abovementioned soil and pest management strategies depends on geography (location), soil condition, climate and size of farm. It is recommended that growers experiment on a small scale before adopting any pest management practice on a large scale. Some of these practices may be economical on 0.5 acre (0.2 ha), and may not be on 100 acres (40 ha).

Growers' skills increase with each season they farm. Growers may find that some farming activities, such as cultivation and planting of certain pestresistant crops, are important to reduce certain soil diseases or break certain insect life cycles; others will gain experience in manipulating soil disease and nematode populations by using certain types and quantities of organic amendments. Improving soil quality and suppressing pests to economical levels may aid in reducing yield losses and increasing profits.

Although these practices are considered site-specific, the following suggested guidelines could be helpful in managing pests during the transition period wherever applicable.
1) Prevention of annual weeds from producing seeds (e.g., frequent mowing and/or flaming).

2) Designing a crop rotation that reduces certain noxious pests (e.g., nematode-resistant cover crops) and enhances soil organic carbon accumulation.

3) Manipulating planting dates (e.g., plant immediately after cultivation may allow establishment of crop plants before regrowth of weeds and break insect life cycles).

4) Hand pulling of weeds, if necessary. 5) Increasing crops' seeding rates to minimize weed density (e.g., an increase in crop density provides shading that may reduce weed emergence and growth).

6) Using pest-free stocks and pest-resistant crop varieties (virus-, fungus-, or nematode-resistant crops).

7) Soil solarization, in regions with warm and sunny climate, to reduce soilborne pathogens and other pests.

\section{Literature cited}

Ayers, Q.C. 1936. Soil erosion and its control. McGraw-Hill, New York.

Bowman, G., C. Shirley, and C. Cramer. 1998. Managing cover crops profitability. $2^{\text {nd }}$ ed. Sustainable Agr. Network Hdbk. Ser. Book 3.

Canter, L.W. 1996. Nitrates in groundwater. Lewis Publ., Boca Raton, Fla.

Clark, M.S., W.R. Horwath, C. Shennan, and K.M. Scow. 1998. Changes in soil chemical properties resulting from organic and low-input farming practices. Agron. J. 90:662-671.

Corbett, A. and J.A. Rosenheim. 1996. Impact of a natural enemy over wintering refuge and its interaction with the surroundinglandscape. Ecol. Entomol. 21:155-164.

Dabney, S.M., J.A. Delgado, and D.W. Reeves. 2001. Using winter cover crops to improve soil and water quality. Commun. Soil Sci. Plant Anal. 32:1221-1250.

Decaens, T., A.F. Rangel, N. Asakawa, and R.J. Thomas. 1999. Carbon and nitrogen dynamics in aging earthworm casts in grasslands of the eastern plains of Colombia. Biol. Fert. Soils. 30:20-28.

Dunn, J.A. 1995. Organic food and fiber: An analysis of 1994 certified production in the United States. USDA Agr. Mktg. Serv., Wash., D.C.

Fernandez-Cornejo, J., C. Greene, R. Penn, and D. Newton. 1998. Organic vegetable production in the U.S.: Certified growers and their practices. Amer. J. Alt. Agr. 13:6978 
Gallaher, R.N. and R. McSorley. 1993. Population densities of Meloidogyne incognita and other nematodes following seven cultivars of cowpea. Nematropica 23:21-26.

Gallards-Lara, F. and R. Nogales. 1987. Effect of the application of town refuse compost on the soil plant system. Biol. Wastes 10:35-62.

Gaskell, M. 1999. Agronomic and economic evaluation of seven organic nitrogen fertilizers applied to bell peppers. HortScience 34:199 (abstr.).

Gaskell, M., B. Fouche, S. Koike, T. Lanini, J. Mitchell, and R. Smith. 2000. Organic vegetable production in California-Science and practice. Hort Technology 10:699-713.

Greens, C.R. 2001. U.S. Organic farming emerges in the 1990's: Adoption of certified systems. USDA Econ. Res. Serv. Resource Econ. Div. Agr. Info. Bul. 770.

Halford, P.D., M.D. Russell, and K. Evans. 1999. Use of resistant and susceptible potato cultivars in the trap cropping of potato cyst nematodes, Globodera pallida and $G$. rostochiensis. Ann. Appl. Biol. 134:321-327.

Hamilton, P.A. and D.R. Helsel. 1995. Effects of agriculture on ground-water quality in five regions of the United States. Ground Water 33:217-226.

Hoffmann, G. 1983. Recycling of municipal waste compost in vineyard soils, p. 69. In: B. Novak (ed.). Studies about humus. Trans. VIII Intl. Symp. vol. I. (abstracts), Prague, Czech Republic.

Jackson, L.E., L.J. Wyland, and L.J. Stivers. 1993. Winter cover crops to minimize nitrate losses in intensive lettuce production. J. Agr. Sci. 121:55-62.

Katan, J. and J.E. DeVay. 1991. Soil solarization: Historical perspective, principles and uses, p. 23-27. In: J. Katan and J.E. DeVay (eds.). Soil solarization. CRC Press, Boca Raton, Fla.

Khaleel, R., K.R. Reddy, and M.R. Overcash. 1981. Changes in soil physical properties due to organic waste applications. J. Environ. Qual. 10:133-141.

Kristiansen, P. 2000. Sustainable weed management in organic herb and vegetable production. 7 Jan. 2002. <http://www.une. edu.au/agronomy/weedsl.html>.

Lampkin, N.H. and S. Padel. 1994. The economics of organic farming: An international perspective. CAB Intl., Oxon, U.K.

McGovern, R.J. and J.P. Begeman. 1996. Reduction of phytophthora blight of Madagascar periwinkle in the landscape by soil solarization. Fla. State Hort. Soc. 108:5860 .

McSorley, R. 1998. Alternative practices for managing plant-parasitic nematodes. Amer.

\section{J. Alt. Agr. 13:98-104.}

McSorley, R. and R.N. Gallaher. 1995. Cultural practices improve crop tolerance to nematodes. Nematropica 25:53-60.

Morse, R.D. 1999. No-till vegetable production-Its time is now. HortTechnology 9:373-379.

Muehlbauer, F.J. 1996. Advances in the production of cool season food legumes. Amer. J. Alt. Ag. 11:71-76.

Oelhaf, R.C. 1978. Organic agriculture: Economic and ecological comparisons with conventional methods. Allanheld, Osmun, Montclair, N.J.

Ofori, C.F. and W.R. Stern. 1987. Cereallegume intercropping systems. Adv. Agron. 26:177-204.

Opperman, C.H., J.R. Rich, and R.A. Dunn. 1988. Reproduction of three root-knot nematodes on winter small grain crops. Plant Dis. 72:869-871.

Papendick, R.I. and R.J. Cook. 1974. Plant water stress and the development of Fusarium foot rot in wheat subjected to different cultural practices. Phytopathology 64:358-363.

Papendick, R.I. and L.F. Elliot. 1984. Tillage and cropping systems for erosion control and efficient nutrient utilization, p. 6981. In: D.F. Bezdicek, J.F. Power, D.R. Keeney, and M.J. Wright (eds.). Organic farming: Current technology and its role in a sustainable agriculture. Amer. Soc. Agron. Special Publ. 46.

Peters, S. 1991. Organic and conventional beyond transition. Org. Farmer 11(1):1-5.

Rasse, D.P., J.T. Ritchie, W.R. Peterson, J. Wei, and A.J.M. Smucker. 2000. Rye cover crop and nitrogen fertilization effects on nitrate leaching in inbred maize fields. J. Environ. Qual. 29:298-304.

Sartain, J.B. 1990. Leaching studies involving selected slow-release $\mathrm{N}$ sources, p. 7784. In: T.E. Freemen (ed.). Turfgrass research in Florida-A technical report. Univ. Fla., Gainesville.

Scow, K.M., O. Somasco, N. Gunapala, S. Lau, R. Venette, H. Ferris, R. Miller, and C. Shennan. 1994. Transition from conventional to low-input agriculture changes soil fertility and biology. Calif. Agr. 48:20-26.

Snyder, G.H., B.J. Augustin, and J.M. Davidson. 1984. Moisture sensor controlled irrigation for reducing nitrogen leaching in bermudagrass turf. Agron. J. 76:964-969.

Teasdale, J.R. 1993. Interaction of light, soil, moistures, and temperature with weed suppression by hairy vetch residue. Weed Sci. 4l:46-51.

Temple, S.R., O.A. Somasco, M. Kirk, and
D. Friedman. 1994. Conventional, low input, and organic farming systems compared. Calif. Agr. 48:14-19.

Thompson, G. 2000. International consumer demand for organic foods. HortTechnology 10:663-674.

U.S. Department of Agriculture. 1980. Report and recommendations on organic farming. A special report prepared for the Secretary of Agriculture. U.S. Govt. Printing Office, Wash., D.C.

U.S. Department of Agriculture. 1990. Federal organic foods production act of 1990. Agr. Mktg. Serv., Natl. Organic Prog., Wash., D.C. 7 Jan. 2002. <http://www.ams.usda. gov/nop/orgact.htm>.

U.S. Department of Agriculture. 2000. News release. Glickman announces national standards for organic food. 7 Jan. 2002. <http:/ /www.usda.gov/news/releases/2000/ 12/0425.htm>.

U.S. Department of Agriculture. 2001. Atmosphericimpact of agricultural use of $\mathrm{MeBr}$. 7 Jan. 2002. <http://www.ars.usda.gov/ is $/ \mathrm{np} / \mathrm{mba} /$ aprol $/$ agric.htm $>$.

Voss, R.D. and W.D. Shrader. 1984. Rotation effects and legume sources of nitrogen for corn, p. 61-68. In: D.F. Bezdicek, J.F. Power, D.R. Keeney, and M.J.Wright (eds.). Organic farming: Current technology and its role in a sustainable agriculture. Amer Soc. Agron. Special Publ. 46.

Wang, K., G. Ferguson, and J.L. Shipp. 1997. Incidence of tomato pinworm, Keiferia lycopersicella (Walsingham), (Lepidoptera: Gelechiidae) on greenhouse tomatoes in southern Ontario and its control using mating disruption. Proc. Entomol. Soc. Ontario 128:93-98.

Weaver, D.B., R. Kabana Rodriguez, and E.L. Carden. 1998. Velvetbean and bahiagrass as rotation crops for management of Meloidogyne spp. and Heterodera glycines in soybean. J. Nematol. 30(suppl.):563-568.

Willumsen, J. and K. Thorup-Kristensen. 2001. Effects of green manure crops on soil mineral nitrogen available for organic production of onion and white cabbage in two contrasting years. Intl. J. Biol. Agr. Hort. 18:365-384.

Yepsen, Jr., R.B. 1976. Organic plant protection. Rodale Press, Emmaus, Pa.

Zinati, G.M., Y.C. Li, and H.H. Bryan. 2001. Utilization of compost increases organic carbon and its humin, humic and fulvic acid fractions in calcareous soil. Compost Sci. Utilization 9:156-162.

Zinati, G.M. and E.R. Emino. 2002. Effect of co-compost on sandy soil properties for specialty cut-flower production. HortScience (in press). 